\title{
Introduction to the special issue about perspectives on teachers' disciplinary knowledge of reading processes, development, and pedagogy
}

\author{
Anne Cunningham · Jamie Zibulsky
}

Published online: 30 January 2009

(C) The Author(s) 2009. This article is published with open access at Springerlink.com

\section{Introduction}

Reading acquisition is arguably the most complex, developmentally interesting cognitive task that children are expected to undertake while in school. Although there is growing recognition that certified and highly trained teachers positively influence student learning and development (Darling-Hammond, 2000), the effective teaching of literacy skills requires not only knowledge cultivated through basic pre- and in-service programs, but also that educators acquire and apply a sophisticated understanding of the nuances of the English language. Additionally, the increasing diversity of students' cognitive, linguistic, and academic abilities in today's classrooms has put even greater pressure on teachers to develop varied strategies that will foster student literacy growth. Similarly, as we aim to support the literacy development of all children both before and throughout their formal education, it is important to recognize that teachers at different grade levels must acquire different types of knowledge and utilize different strategies in order to best support their students. As our education system attempts to identify the most effective strategies to minimize the discrepancies between underserved and more advantaged populations, it is critical that both educators and researchers recognize the powerful impact that teacher knowledge of early literacy skills can have on students' long-term academic success and continue empirical explorations of exactly how, when, and why teachers have this influence.

In the past three decades, the field of teacher knowledge in the domain of literacy has grown considerably. Researchers have continued to more specifically characterize the knowledge that teachers and teacher educators must acquire and apply (Almasi, 2002; Ball, 2000; Joshi et al., 2009; Shulman, 1986, 1987), craft professional development programs that help teachers cultivate such knowledge (McCutchen

A. Cunningham $(\bowtie) \cdot$ J. Zibulsky

University of California, Berkeley, CA, USA

e-mail: acunning@berkeley.edu 
et al., 2002; Spear-Swerling \& Brucker, 2003), and develop instruments that provide reliable and valid estimates of teacher knowledge (Ball, Phelps, Rowan, \& Schilling 2003; Moats, 1994; Cunningham, Perry, Stanovich, \& Stanovich, 2004; Moats \& Foorman, 2003; Phelps \& Schilling, 2004). This theoretical work is based on the premise that it is entirely possible to examine the disciplinary knowledge base of teachers, ascertain how this knowledge base is associated with student outcomes, and then develop empirically validated "best practices" in literacy instruction based on the knowledge of teachers that is most predictive of student gains. However, research inquiries into each step of this process are still ongoing and we do not yet have the definitive answers we need in order to shift teacher knowledge and instructional practices in ways that will support literacy development. Nascent research demonstrates that teacher knowledge is associated with student literacy gains, yet the field continues to grapple with questions such as how teacher knowledge and practices are associated with one another, how disciplinary knowledge is related to responsive teaching or pedagogical content knowledge, and how one can best measure these knowledge constructs.

This Special Issue addresses the closely related topics of how researchers should go about measuring teacher knowledge, and the relationship between such knowledge and the development of students' literacy skills. Each of the articles included in this Special Issue add to this burgeoning field of study by examining what teachers need to know to provide effective reading instruction, especially for children in the early stages of reading acquisition. The articles included herein provide compelling evidence regarding the type of professional development programs that should be implemented more widely, while simultaneously addressing the need for validated instruments that can measure the type of pedagogical content knowledge such programs aim to develop.

In her eloquent and thoughtful appeal, Louisa Moats highlights the myriad contemporary challenges facing the teaching profession. She catalogs political, systemic, and individual reasons that actual teacher knowledge in the domain of literacy is far removed from the knowledge researchers propose necessary for effective teaching and learning. She goes on to provide a comprehensive literature review of what teachers do indeed know, based on recent studies, and how such knowledge informs instructional practices and student learning. Offering a critique of current practices, Moats argues that preparing teachers to follow a scripted reading program is not sufficient, claiming that in addition to being able to impart a given curriculum, teachers need to be able to analyze student progress and respond dynamically to the variability in student performance. This position provides a lens through which to interpret the professional development strategies and subsequent findings of other researchers whose work is included in this Special Issue.

McCutchen, Green, and Abbott focus on the impact of a professional development program on the performance of struggling third through fifth grade readers. The authors conducted a 10-day summer institute to educate teachers about the importance of utilizing their understanding of phonological awareness and morphology in literacy instruction. They examined the effect that this program had over the course of the following school year, looking both at teacher practices and student gains. Although they found that performance on an iteration of Moats' (1994) 
Informal Survey of Linguistic Knowledge survey was not globally associated with teaching practices, researchers and practitioners alike will be interested to read that teacher knowledge was associated with student gains, particularly for low-performing students. This article provides us with both a simple empirical finding (i.e., teacher knowledge supports student growth) and a puzzling question to study further (i.e., what, if not shifts in instructional practices, led to student growth in these knowledgeable teachers' classrooms?).

By exploring individual differences among teachers in their responses to instruction during professional development, Brady et al, provide a complement to this question. These researchers examined the effects of an intensive year-long professional development program intended to build first-grade teachers' knowledge in the areas of phonological awareness and phonics. Their approach to professional development is detailed in the article and provides a framework for other researchers to work from when piloting similar studies. Through including measures of teachers' attitudes towards literacy instruction and the professional development program itself, as well as exploring teachers' feelings of efficacy in this domain, the authors add an affective component to our understanding of the knowledge required of teachers. They make a compelling case for ongoing professional development efforts that include sustained personal relationships between teachers and highly trained mentors who have the capacity to visit classrooms and consult personally over the course of a year, reminding researchers and program developers that the success of such programs cannot be reduced to merely examining whether specific skills, such as phonological awareness, were transmitted to teachers properly.

Yet, in this era of increasing accountability standards, it is essential that researchers can articulate the benefits of teacher professional development by documenting significant relationships between teacher knowledge gains and student learning. Despite the fact that many practitioners can intuit when a program or curriculum is working well, it takes a skilled researcher to ask the right questions and quantify what works. Carlisle, Correnti, Phelps, and Zeng, quite responsibly, push the field to further clarify the relationship between teacher knowledge and student outcomes by operationalizing each of these important variables in precise and valid ways. First, they note that little research has been conducted to develop and validate measures of teacher knowledge about early reading. Further, they point out that there is a dearth of evidence demonstrating that teacher performance on existing measures of such knowledge is associated with student gains. They then go on to examine whether performance on their test of teacher knowledge accounts for first through third grade student reading gains. Through analyzing the effect of teacher knowledge in such a narrow and clearly defined way, and exploring in great depth why their measure of teacher knowledge was not significantly associated with student gains, this article provides other researchers with a fruitful model for future study. The authors end their paper with a call for more comprehensive measures of pedagogical content knowledge. The future of the field depends on the type of scrupulous examination that Carlisle and her colleagues engage in throughout this study.

All of the authors whose work is included in this Special Issue should be commended not only for their scholarship, but also for the incisive inquiries they make into their own practice. By examining the limitations of their own measures of 
teacher knowledge and the quality of their professional development curricula, they model the best practices that should be implemented in this young field of study. We know teacher knowledge in the domain of literacy varies widely, and that strong professional development programs empower teachers and students. However, researchers have yet to specify and operationalize the knowledge teachers need to acquire, and how this knowledge is associated with student gains in specific skills. It is our hope that this Special Issue moves us in that direction.

Open Access This article is distributed under the terms of the Creative Commons Attribution Noncommercial License which permits any noncommercial use, distribution, and reproduction in any medium, provided the original author(s) and source are credited.

\section{References}

Almasi, J. (2002). Teaching strategic processes in reading. NY: Guilford Press.

Ball, D. L. (2000). Bridging practices: Intertwining content and pedagogy in teaching and learning to teach. Journal of Teacher Education, 51, 241-247. doi:10.1177/0022487100051003013.

Ball, D. L., Phelps, G., Rowan, B., \& Schilling, S. (2003). Measuring teachers' content knowledge for teaching reading: Elementary reading release items. Ann Arbor, MI: Study of Instructional Improvement.

Cunningham, A. E., Perry, K. E., Stanovich, K. E., \& Stanovich, P. J. (2004). Disciplinary knowledge of K-3 teachers and their knowledge calibration in the domain of early literacy. Annals of Dyslexia, 54, 139-172. doi:10.1007/s11881-004-0007-y.

Darling-Hammond, L. (2000). How teacher education matters. Journal of Teacher Education, 51, 166-173. doi:10.1177/0022487100051003002.

Joshi, R. M., Binks, E., Hougen, M., Ocker-Dean, E., Graham, L., \& Smith, D. (2009). Teachers' knowledge of basic linguistic skills: Where does it come from? In S. Rosenfield \& V. Berninger (Eds.), Handbook on implementing evidence based academic interventions (pp. 851-877). New York: Oxford University Press.

McCutchen, D., Abbott, R. D., Green, L. B., Beretvas, S. N., Cox, S., Potter, N. S., et al. (2002). Beginning literacy: Links among teacher knowledge, teacher practice, and student learning. Journal of Learning Disabilities, 35, 69-86. doi:10.1177/002221940203500106.

Moats, L. (1994). The missing foundation in teacher education: Knowledge of the structure of spoken and written language. Annals of Dyslexia, 44, 81-102. doi:10.1007/BF02648156.

Moats, L. C., \& Foorman, B. R. (2003). Measuring teachers' content knowledge of language and reading. Annals of Dyslexia, 53, 23-45. doi:10.1007/s11881-003-0003-7.

Phelps, G., \& Schilling, S. (2004). Developing measures of content knowledge for teaching reading. The Elementary School Journal, 105, 31-48. doi:10.1086/428764.

Shulman, L. (1986). Those who understand: Knowledge growth in teaching. Educational Researcher, 15, 4-14.

Shulman, L. (1987). Knowledge and teaching: Foundations of the new reform. Harvard Educational Review, 57, 1-22.

Spear-Swerling, L., \& Brucker, P. (2003). Teachers' acquisition of knowledge about English word structure. Annals of Dyslexia, 53, 72-103. doi:10.1007/s11881-003-0005-5. 